J. Clin. Chem. Clin. Biochem.

Vol. 26, 1988, pp. 3-6

(C) 1988 Walter de Gruyter \& Co.

Berlin · New York

\title{
Effects of the Antithrombotic Drug Suloctidil on Low Density Lipoprotein Processing and Cholesterol Metabolism in Cultured Human Fibroblasts
}

\author{
By Cécile Mazière, J.-C. Mazière, Nacer-Eddine Houtia, J. Lauga ${ }^{1}$ and J. Polonovski \\ Faculté de Médecine Saint-Antoine, Service de Chimie Biologique and U.A 524 du CNRS, Paris, France
}

(Received February 16/October 7, 1987)

Summary: Human foetal lung fibroblasts were pretreated for $24 \mathrm{~h}$ with the antithrombotic drug, suloctidil ( 1 to $10 \mu \mathrm{mol} / 1$ ), which induced a dose-dependent increase in LDL binding, uptake and degradation. At $10 \mu \mathrm{mol} / 1$ suloctidil, the respective increases in these parameters were $40 \%, 80 \%$ and $50 \%$. The same treatment also resulted in increases of 1.5 to 2-fold in the synthesis of sterols, fatty acids and triacylglycerols from sodium acetate. In contrast, the esterification of cholesterol with oleic acid was specifically decreased by $35 \%$ by $24 \mathrm{~h}$ pretreatment of fibroblasts with $10 \mu \mathrm{mol} / 1$ suloctidil. A similar decrease of cholesterol esterification was observed in cholesterol-laden fibroblasts. It is suggested that these effects of suloctidil on LDL processing and cholesterol metabolism are related to the amphiphilic characteristics of the drug and to its calciumblocking properties.

\section{Introduction}

After binding to receptors, LDL uptake and degradation by culturèd fibroblasts result in repression of endogenous cholesterol synthesis and stimulation of cholesterol esterification $(1,2)$. The importance of this pathway arises from the fact that a decrease in LDL receptor number, as observed in familial hypercholesterolaemia $(3,4)$, leads to premature atherosclerosis. Besides the hormonal control of this pathway by insulin (5) or epinephrine (6), it has been demonstrated that some amphiphilic drugs, such as phenothiazines (7), propranolol (8), or AY $9944(9,10)$, stimulate the LDL receptor pathwayy. This effect is probably mediated by a direct action of the drugs on the phospholipid bilayer.

Suloctidil (1-(4-isopropylthiophenyl)-2-n-octylaminopropanol) was originally used as an antispasmodic agent for the treatment of cerebral and peripheral artery insufficiencies $(11,12)$. Subsequently, it was observed that this drug also inhibits platelet aggregation $(13,14)$ and prevents experimentally induced

') Laboratoires SEARLE, Département Médical. thrombosis $(15,16)$. It was also demonstrated that suloctidil inhibits calcium influx $(17,18)$, perhaps by affecting membrane fluidity (19). Because of its amphiphilic character, suloctidil has the property of binding readily to cell membranes, especially to the acidic phospholipids (20).

In this work, the effect of suloctidil on LDL binding, internalization and degradation was investigated. Cholesterol synthesis and esterification have been also shown to be affected by suloctidil.

\section{Materials and Methods}

Cell culture

MRC5 (human foetal lung) fibroblasts were purchased from Biomérieux France, and maintained in Nunc flasks with Dulbecco's medium (Gibco) supplemented with $10 \%$ foetal calf serum (Gibco) at $37^{\circ} \mathrm{C}$, in a $5 \% \mathrm{CO}_{2}$ atmosphere. For experiments, cells are taken at confluency, in $35 \mathrm{~mm}$ Nunc Petri dishes containing approximately $2 \times 10^{5}$ cells.

\section{LDL preparation and labeling}

LDL was prepared from normal human serum by 3 stepultracentrifugation at $105000 \mathrm{~g}$ in a L5.50 Beckman ultracen- 
trifuge, according to Havel et al. (21). The LDL was taken as the $1.024-1.050 \mathrm{~kg} / 1$ density fraction. ${ }^{125}$ Iodine labeling was performed by the method of Bilheimer et al. (22).

Effect of suloctidil on LDL binding, uptake and degradation

For maximal induction of LDL receptors, cells were pretreated for $24 \mathrm{~h}$ with suloctidil (Searle Lab.) in ethanol solution (final ethanol concentration $0.5 \%$ ) in medium devoid of serum, supplemented with $2 \%$ serum substitute Ultroser $G$ (Industries Biologiques Françaises). Cells were then washed twice, and LDL binding, uptake and degradation studied according to Goldstein \& Brown (4). Incubations were performed for $2 \mathrm{~h}$ at $4^{\circ} \mathrm{C}$ for binding studies, and $4 \mathrm{~h}$ at $37^{\circ} \mathrm{C}$ for uptake and degradation studies, in $0.5 \mathrm{ml} \mathrm{Ham} \mathrm{F10,10} \mathrm{mmol/1} \mathrm{Hepes} \mathrm{pH}$ 7.4 medium. The final concentration of LDL in the incubation medium was $10 \mathrm{mg} / \mathrm{l}$. After incubation, cells were washed 4 times with a phosphate-buffered solution ( $\mathrm{pH} 7.4)$, harvested with a rubber policeman and centrifuged for $5 \mathrm{~min}$ at $400 \mathrm{~g}$. The radioactivity associated with the pellet was measured with a Packard 256 gamma-counter. For the study of [ $\left.{ }^{125} \mathrm{I}\right] \mathrm{LDL}$ degradation, the incubation medium $(0.5 \mathrm{ml})$ was removed before cell washing and $0.25 \mathrm{ml}$ of $500 \mathrm{~g} / \mathrm{l}$ trichloroacetic acid was added. The samples were maintained at room temperature for $10 \mathrm{~min}$. The precipitate was centrifuged for $10 \mathrm{~min}$ at $4000 \mathrm{~g}$. Ten microlitres of $400 \mathrm{~g} / 1 \mathrm{KI}$ and $50 \mu \mathrm{l}$ of $300 \mathrm{~g} / \mathrm{kg} \mathrm{H}_{2} \mathrm{O}_{2}$ were then added to $0.5 \mathrm{ml}$ of the supernatant. After mixing, the samples were maintained for $30 \mathrm{~min}$ at $4{ }^{\circ} \mathrm{C}$, then extracted with $2 \mathrm{ml}$ chloroform, and radioactivity counted on $0.2 \mathrm{ml}$ of the upper phase. Results are calculated in $\mathrm{ng}$ LDL per $\mathrm{mg}$ of cell protein and then expressed as fraction of control value. Protein was determined by the method of Lowry et al. (23).

\section{Effect of suloctidil on cholesterol metabolism}

Experiments were performed with sodium $\left[1-{ }^{14} \mathrm{C}\right]$ acetate $(1.77$ $\mathrm{GBq} / \mathrm{mmol}$, CEA France) or $\left[1-{ }^{14} \mathrm{C}\right]$ oleic acid $(1.92 \mathrm{GBq} / \mathrm{mmol}$, Amersham). Cells were pretreated for $24 \mathrm{~h}$ with suloctidil. After evaporation to dryness in a nitrogen stream, oleic acid was resuspended for $15 \mathrm{~min}$ at $37^{\circ} \mathrm{C}$ in a fatty acid-free human serum albumin solution $0.2 \mathrm{~g} / 1$. Radioactive sodium acetate $(1.11 \mathrm{GBq} / \mathrm{l})$ or oleic acid $(18.5 \mathrm{MBq} / \mathrm{l})$ was then added and a further $4 \mathrm{~h}$ incubation performed. Cells were washed three times and lipid analysis performed by thin layer chromatography after direct application of the cell suspension on silica gel plates, using a modification of the method described by Dosado et al. (24). Neutral lipids were separated by the solvent system hexane/diethylether/acetic acid 70/30/2 (by vol.) and phospholipids by the solvent system chloroform/methanol/acetic acid/ $\mathrm{H}_{2} \mathrm{O} 50 /$ $30 / 8 / 4$ (by vol.). After autoradiography, the radioactive spots were cut out and counted by liquid scintillation. Results are expressed in pmol of precursor incorporated per mg cellular protein.

\section{Results}

The effects of suloctidil on LDL binding, uptake and degradation are shown in figure 1 , showing that the three parameters were increased after a $24 \mathrm{~h}$ treatment with suloctidil. However, uptake was somewhat more sensitive to suloctidil than binding and degradation. At $10 \mu \mathrm{mol} / \mathrm{l}$, suloctidil induced a 1.4, 1.8 and 1.5 fold increase in binding, uptake and degradation, respectively. At concentrations higher than $10 \mu \mathrm{mol} / \mathrm{l}$, a cytotoxic effect of suloctidil was observed in our system.

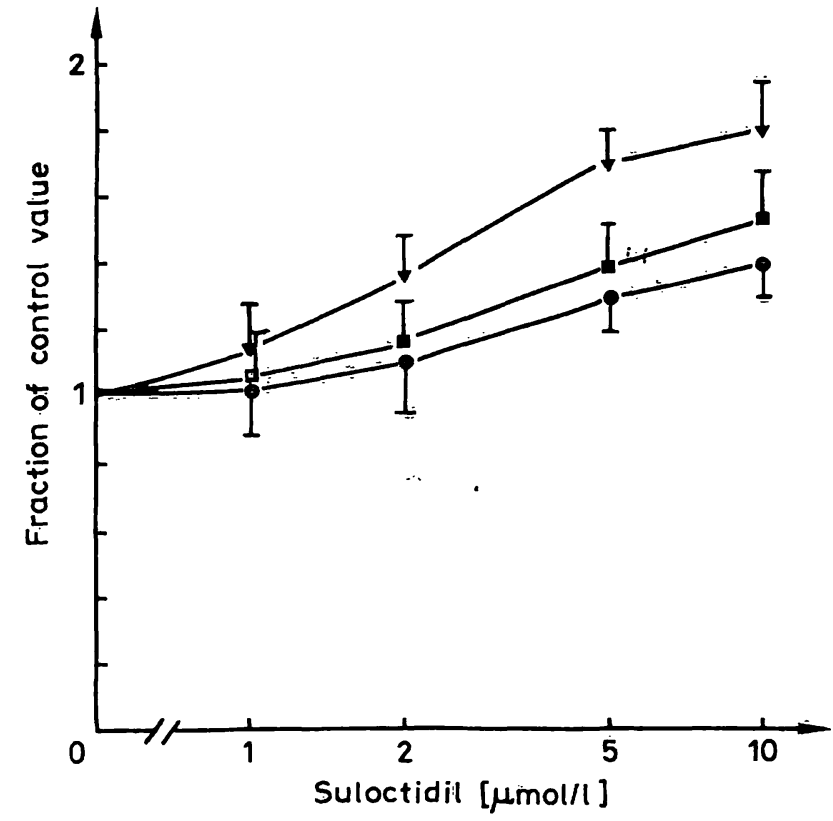

Fig. 1. Effect of suloctidil on LDL binding (๑), uptake ( $\nabla)$ and degradation ( $(\square)$ by cultured human fibroblasts. Cells were treated for $24 \mathrm{~h}$ with suloctidil in ethanol solution (final ethanol concentration $0.5 \%$ ). Binding, uptake and degradation were then measured in the absence of the drug with $10 \mathrm{mg} / 1$ [ $\left.{ }^{125}\right] \mathrm{LDL} 3.33-5.0$ $\mathrm{Bq} / \mathrm{ng}$. Abscissa = suloctidil concentration (mol/l). Ordinate: Fraction of control value. The absolute values (LDL, ng/mg protein) were: $32 \pm 3$ for binding, $194 \pm 11$ for uptake and $297 \pm 19$ for degradation. Means of 4 determinations $\pm S$. D.

Sterol synthesis from sodium acetate and cholesterol esterification with oleic acid were also studied after a $24 \mathrm{~h}$ pretreatment with suloctidil. The results in table 1 demonstrate that suloctidil caused a dose-dependent stimulation of sterol synthesis. At $10 \mu \mathrm{mol} / \mathrm{l}$, sterol synthesis was about 1.8 fold increased. However, it must be noted that this effect was not specific: fatty acid and triacylglycerol synthesis were also increased in the presence of suloctidil, albeit to a lesser extent. As for cholesterol esterification, the results in table 2 indicate that the incorporation of oleic acid into cholesteryl esters was notably decreased in the presence of suloctidil; at $10 \mu \mathrm{mol} / \mathrm{l}$, cholesterol esterification was about one third of that in the controls. This effect appeared to be specific, since the incorporation into triacylglycerols and phospholipids, taken as the internal control, were not affected.

In another set of experiments, oleic acid incorporation into cholesteryl esters was measured in cholesterolladen cells (tab. 3). It can be seen that in the presence of cholesterol $25 \mathrm{~g} / \mathrm{l}$ in ethanol solution, the incorporation into cholesteryl esters, which reflects the activity of the enzyme acylcoenzyme A : cholesterol$\mathrm{O}$-acyl transferase was about 4-fold higher than in non-laden cells. Moreover, the decrease of cholesterol 
Tab. 1. Effect of suloctidil on lipid synthesis from sodium acetate.

\begin{tabular}{lllll}
\hline Addition & \multicolumn{4}{l}{ Sodium acetate (pmol/mg protein) incorporated into } \\
\cline { 2 - 5 } & Sterols & Fatty acids & Triacylglycerols & Phospholipids \\
\hline Control (Ethanol, volume fraction 0.005$)$ & $375 \pm 50$ & $1280 \pm 180$ & $1475 \pm 230$ & $22450 \pm 3650$ \\
Suloctidil (in ethanol, volume fraction 0.005$)$ & $520 \pm 140^{*}$ & $1560 \pm 150$ & $1620 \pm 265$ & $24420 \pm 3950$ \\
$1 \mu \mathrm{mol} / 1$ & $580 \pm 115^{* *}$ & $1870 \pm 190^{* *}$ & $1900 \pm 240^{*}$ & $25610 \pm 4120$ \\
$5 \mu \mathrm{mol} / 1$ & $660 \pm 95^{* *}$ & $2050 \pm 210^{* *}$ & $2110 \pm 250^{*}$ & $28550 \pm 3510^{*}$ \\
$10 \mu \mathrm{mol} / 1$ & & & &
\end{tabular}

For maximal induction of sterol synthesis, cells were pretreated for $24 \mathrm{~h}$ in serum-free medium, supplemented with the serum substitute Ultroser $\mathrm{G}$. Sodium $\left[1-{ }^{14} \mathrm{C}\right]$ acetate $(1.11 \mathrm{GBq} / \mathrm{l})$ was then added and a further $4 \mathrm{~h}$ incubation performed. Lipid separation was performed by thin layer chromatography. Means of 3 experiments $\pm S$. D.

$*=\mathrm{p}<0.05 ; * *=\mathrm{p}<0.01$

Tab. 2. Effect of suloctidil on oleic acid incorporation into lipids.

\begin{tabular}{|c|c|c|c|}
\hline \multirow[t]{2}{*}{ Addition } & \multicolumn{3}{|c|}{$\begin{array}{l}\text { Oleic acid (pmol/mg protein) incorpora- } \\
\text { ted into }\end{array}$} \\
\hline & $\begin{array}{l}\text { Cholesteryl } \\
\text { esters }\end{array}$ & $\begin{array}{l}\text { Triacyl- } \\
\text { glycerols }\end{array}$ & $\begin{array}{l}\text { Phospho- } \\
\text { lipids }\end{array}$ \\
\hline $\begin{array}{l}\text { Control } \\
\text { (ethanol, volume } \\
\text { fraction } 0.005 \text { ) }\end{array}$ & $240 \pm 30^{*}$ & $1610 \pm 250$ & $8330 \pm 910$ \\
\hline $\begin{array}{l}\text { Suloctidil (in } \\
\text { ethanol, volume } \\
\text { fraction } 0.005 \text { ) }\end{array}$ & & & mon tom \\
\hline $\begin{array}{l}1 \mu \mathrm{mol} / \mathrm{l}: \\
5 \mu \mathrm{mol} / 1: \\
10 \mu \mathrm{mol} / 1:\end{array}$ & $\begin{aligned} 170 & \pm 25^{*} \\
130 \pm 20^{* *} & \pm \pm 15^{* * *}\end{aligned}$ & $\begin{array}{l}1775 \pm 295 \\
1530 \pm 200 \\
1720 \pm 300\end{array}$ & $\begin{array}{l}8450 \pm 880 \\
9120 \pm 870 \\
9210 \pm 920\end{array}$ \\
\hline
\end{tabular}

Cells were pretreated for $24 \mathrm{~h}$ with suloctidil in medium supplemented with $10 \%$ foetal calf serum for induction of the enzyme acyl Coenzyme $A$ : cholesterol acyl transferase. [1${ }^{14} \mathrm{C}$ oleic acid $(18.5 \mathrm{MBq} / \mathrm{l})$. was then added and a further $4 \mathrm{~h}$ incubation performed. Lipid analysis was performed by thin layer chromatography. Means of 3 determinations $\pm S$. D.

$*=\mathrm{p}<0.05 ;^{* *}=\mathrm{p}<0.01{ }^{* * *}=\mathrm{p}<0.001$ by Student t-test.

esterification induced by suloctidil in non-laden cells was again observed. This is of interest in view of the fact that in atherosclerotic plaques, cholesterol is deposited in foam cells mainly in the esterified form.

\section{Discussion}

Suloctidil induced an increase of LDL binding by cultured human fibroblasts. This increase might be due to modification of either the number of LDL receptors or of the affinity of LDL receptors. Previous work from our laboratories demonstrated that the effect of amphiphilic drugs on LDL binding is rapid (7) and due to an increase in LDL receptor number (10), probably by unmasking a cryptic pool of unavailable receptors. It is most likely that the amphiphilic drug, suloctidil, exerts its effect on LDL binding by this mechanism.
Tab. 3. Effect of suloctidil on oleic acid incorporation into cholesteryl esters in cholesterol-laden fibroblasts.

\begin{tabular}{|c|c|}
\hline $\begin{array}{l}\text { Incubation } \\
\text { Medium }\end{array}$ & $\begin{array}{l}\text { Oleic acid } \\
\text { (pmol/mg protein) } \\
\text { incorporated } \\
\text { into cholesteryl } \\
\text { esters }\end{array}$ \\
\hline $\begin{array}{l}\text { Control } 1 \\
\text { (Ethanol, volume } \\
\text { fraction } 0.005 \text { ) }\end{array}$ & $112 \pm 9$ \\
\hline $\begin{array}{l}\text { Control } 2 \\
\text { (Ethanol, volume } \\
\text { fraction } 0.01 \text { ) }\end{array}$ & $106 \pm 10$ \\
\hline $\begin{array}{l}\text { Cholesterol } 25 \mathrm{mg} / 1 \\
\text { (Ethanol, volume } \\
\text { fraction 0.005) }\end{array}$ & $391 \pm 32$ \\
\hline $\begin{array}{l}\text { Suloctidil } 10 \mu \mathrm{mol} / 1 \\
\text { (Ethanol volume } \\
\text { fraction } 0.005 \text { ) }\end{array}$ & $28 \pm 4 * * *$ \\
\hline $\begin{array}{l}\text { Cholesterol } 25 \mathrm{mg} / \mathrm{l} \\
+ \text { Suloctidil } 10 \mu \mathrm{mol} / \mathrm{l} \\
\text { (Ethanol, volume } \\
\text { fraction } 0.01 \text { ) }\end{array}$ & $51 \pm 4^{* * *}$ \\
\hline
\end{tabular}

Cells were pretreated for $24 \mathrm{~h}$ with suloctidil in the presence or absence of cholesterol in ethanol solution. $\left[1^{-14} \mathrm{C}\right]$ oleic acid $(9.25 \mathrm{MBq} / \mathrm{l})$ was then added and a further $4 \mathrm{~h}$ incubation performed. Means of 3 determinations \pm S. D.

$* * *=\mathrm{p}<0.001$ by Student $\mathrm{t}$-test.

After binding, LDL receptors are internalized in coated vesicles, which give rise to endosomes (25). Endosomes then reach the Golgi apparatus (26) and finally the lysosomes, where degradation is achieved. The fact that suloctidil increases LDL uptake and degradation suggests that some of these processes are affected by the drug, either directly after intercalation in the phospholipid bilayer (20) or indirectly by its effect on calcium influx $(17,18)$. It is of note that a similar effect on LDL processing was recently described by Stein et al. with another calcium antagonist: verapamil (27). 
A stimulation of sterol synthesis and an inhibition of cholesterol esterification were observed with suloctidil. These results are the reverse of what could be expected if suloctidil only acts through its ability to increase LDL processing. Thus, the effects of suloctidil on cholesterol metabolism are independent of its action on LDL metabolism. Further evidence arises from the fact that for the study of sterol synthesis, suloctidil was introduced in serum-free medium, which thus contained no LDL. It must be noted that the activities of 3-hydroxy-3-methyl-glutaryl-coenzyme $\mathrm{A}$ reductase and acylcoenzyme $\mathrm{A}$ : cholesterolO-acyl-transferase have been shown to be modulated by the physico-chemical properties of cell membranes, especially by membrane microviscosity $(28,29)$. The stimulation of lipid synthesis together with the specific inhibition of cholesterol esterification have also been observed with other amphiphilic drugs such as propranolol and phenothiazines (10). However, the calcium-blocking properties of the drug suloctidil might also be involved, since Ranganathan et al. (30) reported that calcium-blocking agents such as verapamil or diltiazem also stimulate sterol synthesis. Thus, the observed effects of suloctidil on LDL processing and cholesterol metabólism might be related to both its amphiphilic characteristics and its calcium-blocking properties.

\section{References}

1. Brown, M. S., Dana, S. E. \& Goldstein, J. L. (1974) J. Biol. Chem. 249, 789-796.

2. Goldstein, J. L., Dana, S. E. \& Brown, M. S. (1974) Proc. Natl. Acad. Sci. USA 71, 4288-4292.

3. Brown, M. S. \& Goldstein, J. L. (1974) Proc. Natl. Acad. Sci. USA 71, 788-792.

4. Goldstein, J. L. \& Brown, M. S. (1974) J. Biol. Chem. 249, $5153-5162$.

5. Chait, A., Bierman, E. L. \& Albers, J. J. (1979) J. Clin. Invest. 64, 1309-1319.

6. Mazière, C., Mazière, J. C., Mora L., Gardette, J. \& Polonovski, J. (1985) Biochem. Biophys. Res. Commun. 133, 958-963.

7. Mazière, J. C., Mazière, C., Gardette, J., Routier, J. D., Wolf, C., Rainteau, D. \& Polonovski, J. (1983) FEBS Lett. $162,396-399$.

8. Ghiselli, G., Bernini, F., Musanti, R. \& Fumagalli, R. (1981) Biochem. Biophys. Res. Commun. 103, 1060-1068.

9. Mazière, J. C., Mazière, C., Wolf, C., Rainteau, D., Barbu, V., Roux, C. \& Polonovski, J. (1984) Biochem. Biophys. Res. Commun. 122, 955-959.

10. Polonovski, J., Mazière, J. C., Mazière, C., Mora L., Gallié, F., Gardette, J., Barbu, V. \& Roux, C. (1986) In: Lipids and its Pathology (Halpern, M. J., ed.) pp. 19-27, Elsevier Science Publishers.

11. Roba, J., Reuse-Blom, S. \& Lambelin, G. (1976) Arch. Int. Pharmacodyn. Ther. 221, 54-59.

12. Tuma, R. F., Wiedeman, M. P. \& Mayrovitz, H. N. (1976) The Physiologist 19, 394-399.

13. Murer, E. H., Niewiarowski, S. \& Stewart, G. J. (1979) Biochem. Pharmacol. 28, 471-478.

14. De Gaetano, G., Miragliotta, G., Roncucci R., Lansen, J. \& Lambelin, G. (1976) Thromb. Res. 8, 361-371.

15. Roba, J., Claeys, M. \& Lambelin G. (1976) Eur. J. Pharmacol. 37, 265-274.

16. Chamone, D. A. F. \& Vermylen, J. (1977) Thrombos. Haemostas. $38,132-138$.

17. Godfrained, T. (1976) Arch. Int. Pharmacodyn. 221, 342343.

18. Malaisse, W. (1977) Arch. Int. Pharmaçodyn. 228, 339344.

19. Chatelain, P., Reckinger, N. \& Roncucci, R. (1979) Biochem. Pharmacol. 28, 3677-3680.

20. Chatelain, P. \& Ruysschaert, J. M. (1981) Biochem. Pharmacol. 30, 313-317.

21. Havel, R. J., Eder, H. A. \& Bragdon, J. H. (1955) J. Clin. Invest. 34, 1345-1353.

22. Bilheimer, D. W., Eisenberg, S. \& Levy, R. I. (1972) Biochim. Biophys. Acta 260, 212-221.

23. Lowry, O. M., Rosebrough, N. J., Farr, A. L. \& Randall, R. J. (1951) J. Biol. Chem. 193, 265-275.

24. Dosado, E. A., Hsie, A. W. \& Snyder, F. (1976) J. Lip. Res. 17, 285-288.

25. Willingham, M. C. \& Pastan, I. (1980) Cell 21, 67-77.

26. Geisow, M. (1980) Nature 288, 434-436.

27. Stein, O., Leitersdorf, E. \& Stein, Y. (1985) Arteriosclerosis $5,35-44$.

28. Mitropoulos, K. A., Balasubramian, S., Venkatesan, S. \& Reeves, B. E. A. (1978) Biochim. Biophys. Acta 530, 99111.

29. Venkatesan, S. \& Mitropoulos, K. A. (1982) Biochim. Biophys. Acta $710,446-455$.

30. Ranganathan, S., Harmony, J. A. K. \& Jackson, R. L. (1982) Biochem. Biophys. Res. Commun. 107, 217-224.

Cécile Mazière

Faculté de Médecine Saint-Antoine

Service de Chimie Biologique

and U.A 524 du CNRS

27 rue Chaligny

F-75012 Paris 